\title{
Occurrence of Perkinsus sp. in undulated surf clams Paphia undulata from the Gulf of Thailand
}

\author{
Supannee Leethochavalit ${ }^{1, *}$, Kashane Chalermwat ${ }^{2}$, E. Suchart Upatham ${ }^{3}$, \\ Kwang-Sik Choi ${ }^{4}$, Pichan Sawangwong ${ }^{2}$, Maleeya Kruatrachue ${ }^{5}$ \\ ${ }^{1}$ Institute of Marine Science, ${ }^{2}$ Faculty of Science, Department of Aquatic Science and ${ }^{3}$ Faculty of Science, \\ Department of Medical Science, Burapha University, Bangsaen, Chonburi 20131, Thailand \\ ${ }^{4}$ School of Applied Marine Sciences, Cheju National University, Jeju 690-756, Korea \\ ${ }^{5}$ Faculty of Science, Department of Biology, Mahidol University, Phayatai, Bangkok 10900, Thailand
}

\begin{abstract}
The undulated surf clam Paphia undulata supports Thailand's largest shellfishery in the Gulf of Thailand, with landings in 1999 recorded at $70000 \mathrm{t}$ (metric tonnes) $\mathrm{yr}^{-1}$. We report, for the first time, the prevalence of Perkinsus sp. in clams in the Gulf. A monthly survey from January to December 2001 utilizing the fluid thioglycollate medium (FTM) method showed that average monthly prevalence was $84.7 \%(n=360)$. The monthly percentage of infected clams was generally $100 \%$, with low prevalence in May (66.7\%) and no infection in September. The monthly mean infection intensity in terms of Perkinsus sp. cells g ${ }^{-1}$ tissue varied from 0 in September to $187759 \pm$ $18970(x \pm$ SE) in October. No obvious annual variation in intensity and prevalence was observed. Prezoosporangia that developed in FTM were 25 to $75 \mu \mathrm{m}$ in diameter. A few days after incubation in aerated seawater, the prezoosporangia underwent successive binary cell division and formed motile zoospores ( 2 to $5 \mu \mathrm{m}$ long). The zoospores were released into the seawater through a discharge tube formed during the 2- and 4-cell stages. Serial semi-thin sections (1 to $4 \mu \mathrm{m}$ thickness) of clam tissue ( $\mathrm{n}=120$ clams) showed developing trophozoites 3 to $6 \mu \mathrm{m}$ in diameter within gills, connective tissue, gonads and, especially, the digestive glands. Microscopic features of different life stages indicated that Perkinsus sp. in Thailand closely resembled P. olseni (= P. atlanticus) reported in Australia, New Zealand, Korea, Japan, Spain and Portugal.
\end{abstract}

KEY WORDS: Clam $\cdot$ Perkinsus sp. Paphia undulata $\cdot$ Gulf of Thailand $\cdot$ Zoosporulation $\cdot$ Infection intensity $\cdot$ Prevalence

Resale or republication not permitted without written consent of the publisher

\section{INTRODUCTION}

Protozoan parasites of the genus Perkinsus infect many species of marine bivalves throughout the world (Goggin \& Lester 1987, Perkins 1988, Figueras et al. 1992, Park \& Choi 2001, Blackbourn et al. 1998, Bower et al. 1998, Casas et al. 2002, Hine \& Diggles 2002). Parasitized bivalve stocks are usually subject to mass mortalities from infection and result in substantial losses for the associated industries (Mackin 1953, Andrews 1988, Soniat 1996). However, most of our knowledge on protozoan parasites of the genus Perkinsus has come from studies conducted in temperate regions of the world, and only a few studies have been conducted in warm temperate and tropical areas (Lester \& Davis 1981, Goggin \& Lester 1987). Recent surveys of clams, oysters, and mussels from farms and natural harvest grounds in Thailand have shown the presence of several protozoan parasites that have the potential to cause damage to the bivalve shellfish industry in Thailand (Taveekijakarn et al. 2002).

The undulated surf clam Paphia undulata supports Thailand's largest shellfishery in the Gulf of Thailand and Andaman Sea. In general, the clams' harvest grounds consist of consolidated mud substrates within 3 to $7 \mathrm{~km}$ distance from the shoreline. Shellfish 
grounds are located off the coast of several coastal provinces (see Fig. 1) and are harvested year-round. The harvested clams are generally processed for export as canned products, and landings in 1999 reached $70000 \mathrm{t}$, with domestic market values estimated to be around US\$ 15 million (DOF 2002). Reported declines of the resource in many provinces have been attributed to overharvesting. In this study however, we report, for the first time, the prevalence of Perkinsus sp. in undulated surf clams in the Gulf of Thailand. The present study details prevalence and infection intensity of Perkinsus sp. monitored over 12 mo and includes microscopic observations of the trophozoites and zoosporulation patterns.

\section{MATERIALS AND METHODS}

Live commercial-sized clams of approximately $4 \mathrm{~cm}$ shell length were collected from local markets in Chonburi Province (Province No. 4, Fig. 1) on the east-

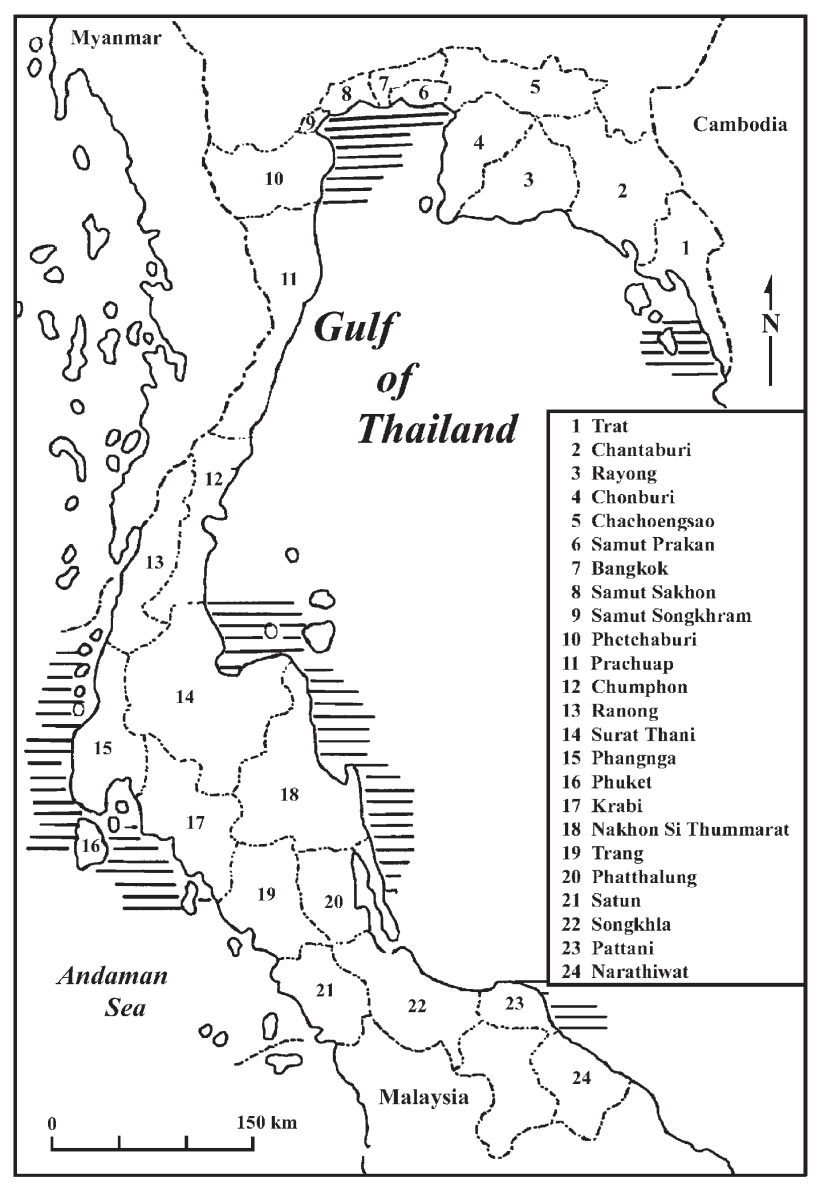

Fig. 1. Coastal provinces of Thailand. Hatched areas: areas in Gulf of Thailand and Andaman Sea where undulated surf clams Paphia undulata have been or are still harvested. (Modified from map by Ole Hagan, Department of Geography, University of Victoria, Canada) ern seaboard of the Gulf of Thailand on a monthly basis from January to December 2001. Each month, 30 whole clams were incubated in $30 \mathrm{ml}$ fluid thioglycollate medium (FTM) per clam supplemented with $500 \mu \mathrm{g} \mathrm{ml}^{-1}$ streptomycin and $500 \mathrm{U} \mathrm{ml}^{-1}$ penicillin-G potassium at room temperature (approximately $27^{\circ} \mathrm{C}$ ) for 7 to $14 \mathrm{~d}$ in darkness (Ray 1966, Almeida et al. 1999). After incubation, whole clams were digested with $30 \mathrm{ml} \mathrm{NaOH}(2 \mathrm{M})$ at $60^{\circ} \mathrm{C}$ for $3 \mathrm{~h}$ (Choi et al. 1989). The samples were then washed with phosphatebuffered saline (PBS) and twice centrifuged at $4500 \times g$ for $15 \mathrm{~min} ; 3$ subsamples of $100 \mu \mathrm{l}$ each were taken and stained with $100 \mu \mathrm{l}$ Lugol's iodine solution, and the hypnospores were enumerated (Bushek et al. 1994). In addition to FMT diagnosis, histology was performed on 10 clams $\mathrm{mo}^{-1}$. After staining with Harris' hematoxylin and counterstaining with eosin (Howard \& Smith 1983), semi-thin sections (1 to $4 \mu \mathrm{m}$ thickness) of paraffin-embedded clams were made through the gills, digestive tract, gonad, mantle and foot to determine the presence of trophozoites in each tissue.

To obtain prezoosporangia for inducing zoosporulation in vitro, the infected tissue was incubated in FTM in darkness for $3 \mathrm{~d}$ at $27^{\circ} \mathrm{C}$. Incubated tissue was then trypsinized by trypsin powder $(0.25 \%)$ for 3 to $4 \mathrm{~h}$ and prezoosporangia were then filtered through silk screens of $120,70,50$, and $20 \mu \mathrm{m}$ mesh size. The prezoosporangia were subsequently washed with filtered seawater and centrifuged twice at $450 \times g$ for 8 min followed by centrifugation at $125 \times g$ and finally $30 \times g$ for $3 \mathrm{~min}$. The prezoosporangia obtained in this way were then placed into petri dishes with aerated filtered seawater fortified with streptomycin $\left(400 \mathrm{\mu g} \mathrm{ml}^{-1}\right)$ and penicillin-G $\left(400 \mathrm{U} \mathrm{ml}^{-1}\right)$. Cultured prezoosporangia were incubated at room temperature $\left(27^{\circ} \mathrm{C}\right)$. Zoosporulation was observed and photographed at frequent intervals under a light microscope.

\section{RESULTS}

The cultivated whole-clam preparations stained with Lugol's iodine showed strong positive results, exhibiting a dark blue color in the gill tissue (Fig. 2). A total of 360 clams $(4.74 \pm 0.34 \mathrm{~cm}$ shell length) $(x \pm \mathrm{SD})$ were analyzed for prevalence and infection intensity using FTM. During the course of the study, mean prevalence was $84.7 \%$ (305 out of 360 clams). Over the $12 \mathrm{mo}$ period, infection intensity varied from 0 to 578573 Perkinsus sp. clam ${ }^{-1}$ or 0 to 187759 cells g $^{-1}$ tissue. The highest infection intensity was observed in October at 578573 cells g $^{-1}$ tissue. Perkinsus sp. was not detected in clams examined in September (Table 1).

FTM incubation resulted in the enlargement of trophozoites to sizes ranging from 25 to $75 \mu \mathrm{m}$. Pre- 


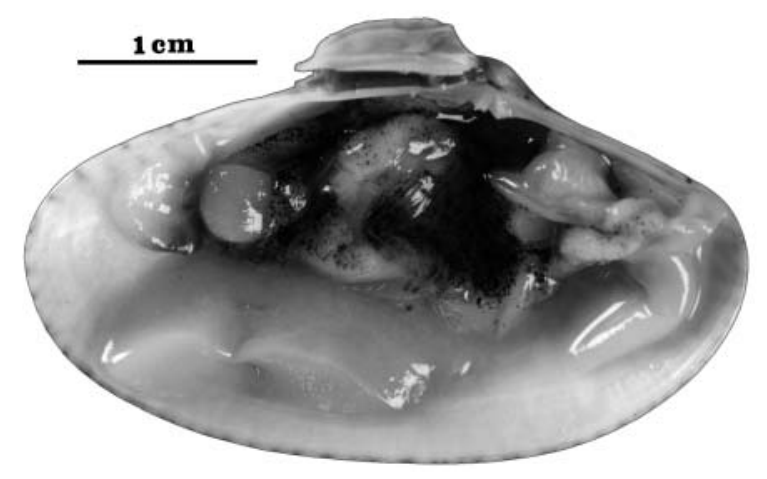

Fig. 2. Paphia undulata. FTM (fluid thioglycollate medium)cultivated, infected clam stained with Lugol's iodine exhibiting dark blue color in gill tissue

zoosporangia (Fig. 3A) were round in appearance, with an eccentric nucleus and large vacuole. Once placed in aerated seawater, prezoosporangia began sporulation characterized by cells with enlarged nuclei and condensed cytoplasm (Fig. 3A). Within $48 \mathrm{~h}$, these cells entered karyo- and cytokinesis, giving rise to a 2-cell stage (Fig. 3B). During this sequence of development, some prezoosporangia developed discharge tubes followed by rapid division resulting in numerous small prezoospores (Fig. 3C,D). Within 3 to $4 \mathrm{~d}$ after incubation in darkness, the prezoospores developed into biflagellated and elongated motile cells within the prezoosporangia (Fig. 3E). At maturation, zoospores were released through a distinct discharge tube (Fig. 3F). The resulting free-swimming zoospores ranged in size from 2 to $5 \mu \mathrm{m}$ in length.

The trophozoites observed in histological preparations under a microscope were round in appearance, varying in diameter from 3 to $6 \mu \mathrm{m}$, and contained a large eccentric vacuole. Clams heavily infected with Perkinsus sp. often showed massive aggregations of hemocytes around the trophozoite. Of the 120 clams prepared for histology, only 28 showed the presence of trophozoites. In these clams, the main tissue of infection was the digestive gland (Fig. 4A), although trophozoites were also present in the muscle (Fig. 4B) and gill (Fig. 4C).

\section{DISCUSSION}

This is the first report of the prevalence of Perkinsus sp. in a commercially harvested tropical clam species. Previous reports of Perkinsus sp. in temperate areas in Asia have been from Korea (Choi \& Park 1997, Park \& Choi 2001), Japan (Hamaguchi et al. 1998, Choi et al. 2002) and China (Liang et al. 2001). In this study, we found that Paphia undulata harvested from natural stocks are infected almost all year round with Perkinsus sp., with a high percentage of infection (up to $100 \%$ ) recorded in 8 of 12 mo. These values are substantially higher than the prevalence reported in Paphia australis from New Zealand (Hine \& Diggles 2002), Crassostrea virginica from South Carolina (Crosby \& Roberts 1990) and Tapes semidecussatus from the northern Mediterranean coast of Spain (Montes et al. 2001). However, these values are similar to the infection intensity in Ruditapes philippinarum in Korea (Park \& Choi 2001). In Chonburi Province, clams that arrive in local markets are harvested from several grounds in the Gulf of Thailand, namely Chonburi, Samut Prakan and Samut Sakhon Provinces (Tharnbuppha 1996) (Province Nos. 4, 6 and 8, respectively, Fig.1). Because of Thailand's location, the average coastal sea temperatures remain around $30^{\circ} \mathrm{C}$, with little seasonal variation. Coastal salinities, however, may fluctuate widely, according to the amount of rainfall. Off the coast of Chonburi Province, coastal salinities range from 20 to $28 \mathrm{ppt}$ on the surface and 22 to 28 ppt near the bottom (BIMS 2002).

Table 1. Perkinsus sp. infecting Paphia undulata. Results of FTM (fluid thioglycollate medium) quantification of Perkinsus sp. in undulated surf clams in Gulf of Thailand; 30 individuals analyzed on each sampling date. Data are means \pm SE

\begin{tabular}{|c|c|c|c|c|c|}
\hline $\begin{array}{l}\text { Sampling date } \\
\text { (2001) }\end{array}$ & $\begin{array}{c}\text { Shell } \\
\text { length }(\mathrm{cm})\end{array}$ & $\begin{array}{l}\text { Wet tissue wt } \\
\qquad(\mathrm{g})\end{array}$ & $\begin{array}{c}\% \\
\text { infection }\end{array}$ & $\begin{array}{l}\text { No. Perkinsus } \\
\text { clam }^{-1}\end{array}$ & $\begin{array}{l}\text { No Perkinsus } \\
\mathrm{g}^{-1} \text { tissue }\end{array}$ \\
\hline 25 Jan & $4.61 \pm 0.24$ & $3.10 \pm 0.54$ & 100 & $141270 \pm 65807$ & $45477 \pm 20214$ \\
\hline $25 \mathrm{Feb}$ & $4.39 \pm 0.16$ & $4.02 \pm 0.9$ & 100 & $89943 \pm 21987$ & $26436 \pm 8281$ \\
\hline $19 \mathrm{Mar}$ & $4.96 \pm 0.22$ & $6.41 \pm 1.48$ & 93.33 & $40210 \pm 6255$ & $6595 \pm 967$ \\
\hline $30 \mathrm{Apr}$ & $4.76 \pm 0.19$ & $5.69 \pm 1.75$ & 100 & $53240 \pm 11959$ & $9904 \pm 1927$ \\
\hline 26 May & $4.15 \pm 0.13$ & $3.03 \pm 0.45$ & 66.66 & $24 \pm 10$ & $7 \pm 3$ \\
\hline 20 Jun & $4.75 \pm 0.26$ & $5.44 \pm 1.28$ & 93.33 & $381026 \pm 69056$ & $68408 \pm 12686$ \\
\hline $12 \mathrm{Jul}$ & $5.27 \pm 0.27$ & $8.69 \pm 1.73$ & 100 & $134127 \pm 21905$ & $14705 \pm 2065$ \\
\hline 10 Aug & $4.93 \pm 0.18$ & $3.84 \pm 0.34$ & 100 & $2301 \pm 402$ & $596 \pm 102$ \\
\hline $14 \mathrm{Sep}$ & $4.71 \pm 0.15$ & $3.25 \pm 035$ & 0 & 0 & 0 \\
\hline 15 Oct & $4.81 \pm 0.20$ & $3.10 \pm 0.52$ & 100 & $578573 \pm 60861$ & $187759 \pm 18970$ \\
\hline $14 \mathrm{Nov}$ & $4.80 \pm 0.19$ & $3.18 \pm 0.52$ & 100 & $275713 \pm 47981$ & $86691 \pm 14768$ \\
\hline $8 \mathrm{Dec}$ & $4.72 \pm 0.20$ & $6.95 \pm 1.34$ & 100 & $518930 \pm 61986$ & $75801 \pm 8991$ \\
\hline Average & $4.74 \pm 0.34$ & $1.73 \pm 2.09$ & 84.72 & $184605 \pm 15607$ & $43530 \pm 4072$ \\
\hline
\end{tabular}




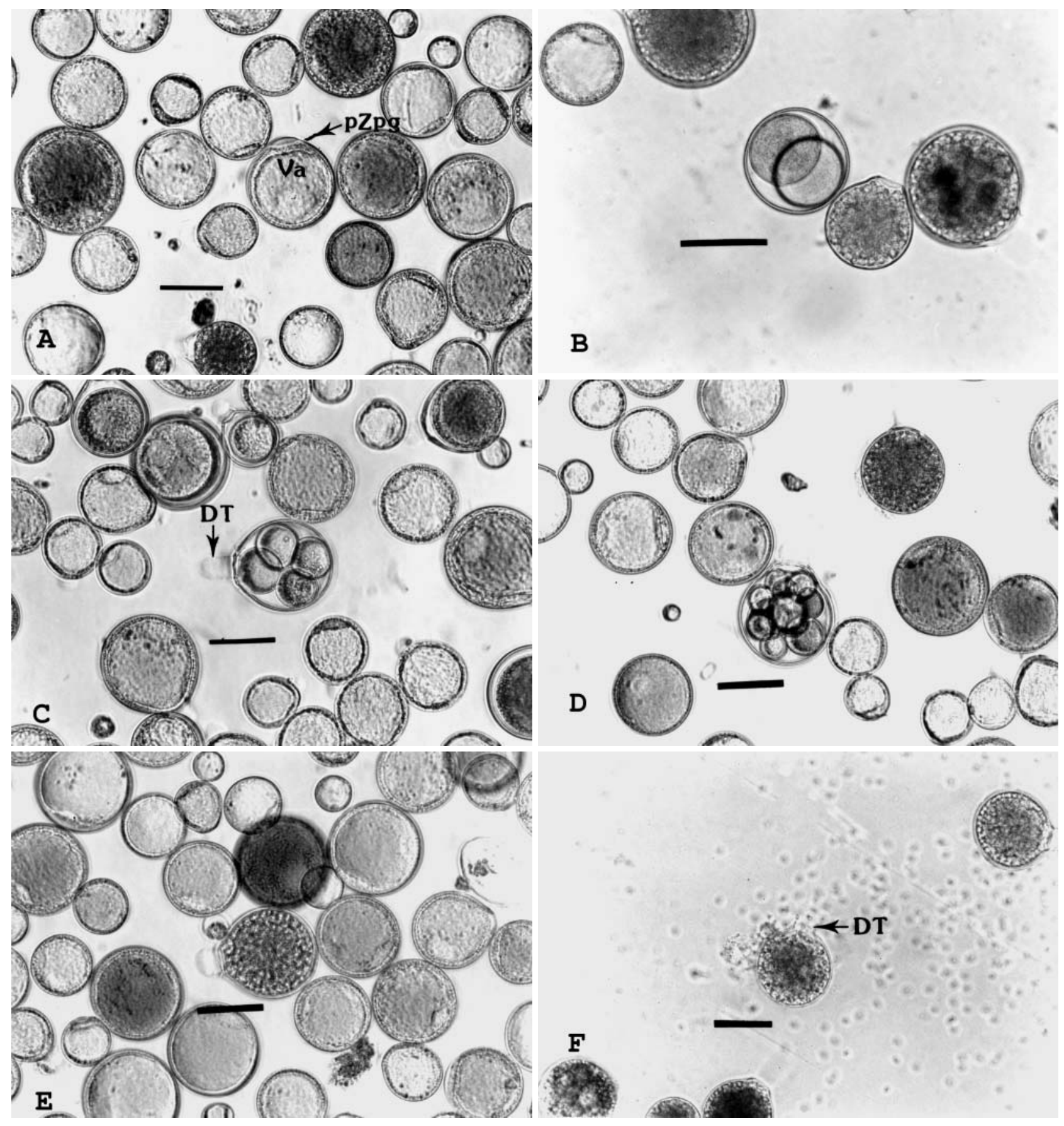

Fig. 3. Light micrograph of zoosporulation of Perkinsus sp. in filtered seawater. (A) Prezoosporangia (pZpg) at beginning of vacuolar (Va) subdivision; (B) 2-cell stage; (C) 4-cell stage showing discharge tube (DT); (D) 8-cell stage; (E) prezoosporangia enclosing numerous motile zoospores; (F) free zoospores released through discharge tube (DT). All scale bars $=50 \mu \mathrm{m}$

Numerous studies have documented the relationship between infection intensity and pathogenicity in relation to salinity for Perkinsus spp. (Andrews 1988, Chu et al. 1993, Burreson \& Ragone Calvo 1996). In the eastern oyster Crassostrea virginica, a critical range for $P$. marinus pathogenicity apparently exists in salinity ranging between 9 and 12 ppt. Salinities as low as 6 ppt are tolerated, but virulence decreases at salinities below 9 ppt (Ragone \& Burreson 1993). Chu \& Greene (1989) reported a salinity range of infection from 6 to $35 \mathrm{ppt}$ for P. marinus. The Thai populations of Paphia undulata are primarily located at sites where salinity and seawater temperatures are high, suggesting a high risk situation for damage to clam stocks from disease. It is not clear, 


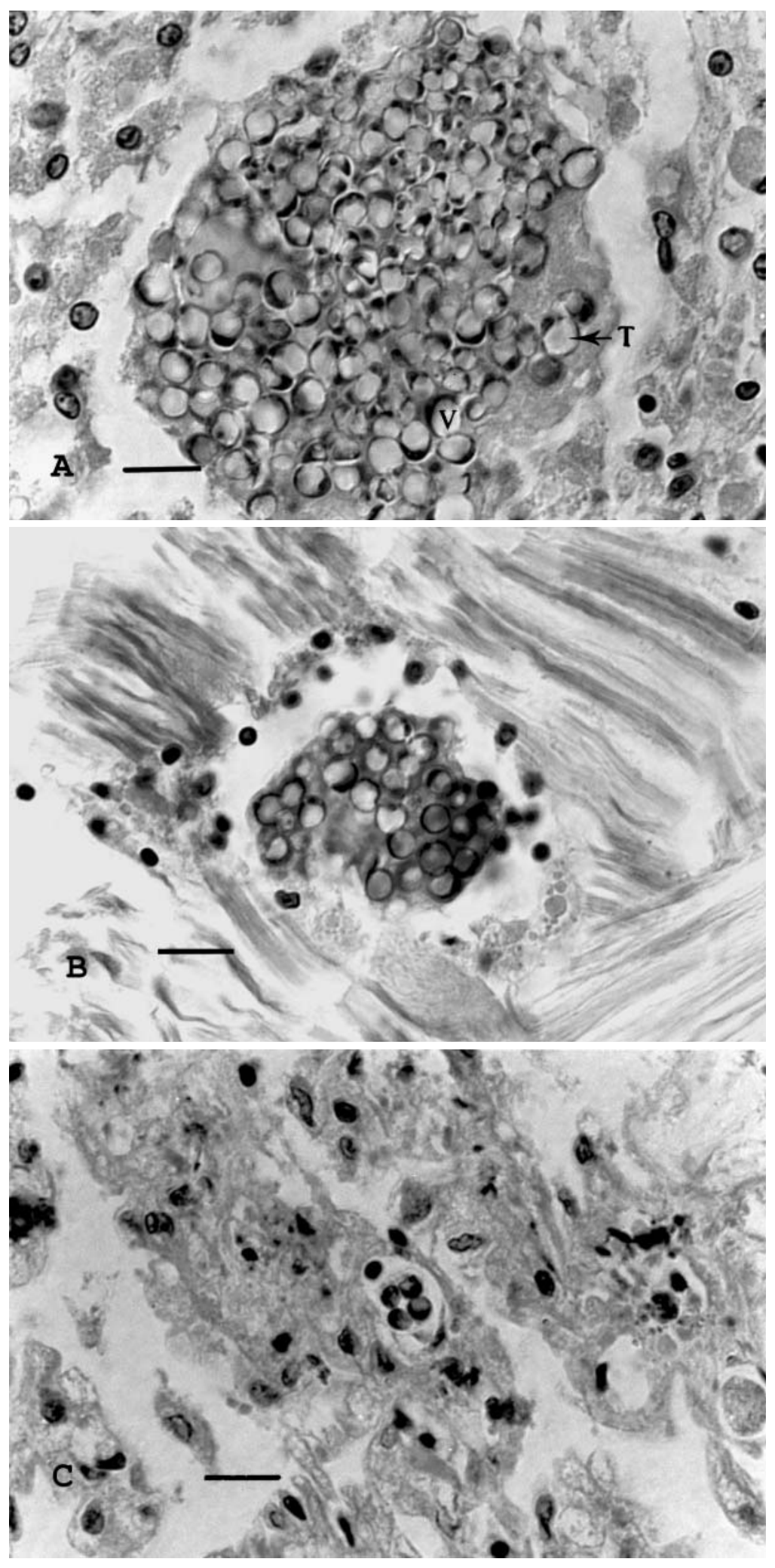

Fig. 4. Perkinsus sp. infecting Paphia undulata. Light micrograph of trophozoites in clam tissue. (A) Eccentric vacuole; (B) trophozoites in muscle tissue; (C) encapsulation of Perkinsus cells in gill tissue. V: vacuole; T: trophozoites. All scale bars $=10 \mu \mathrm{m}$ however, if clam stocks in Thailand are subject to mass mortality from Perkinsus sp. infection, and clarification of this issue warrants further investigation.

The in vitro zoosporulation process of Perkinsus sp. from Paphia undulata appears to be similar to karyo- and cytokinesis in Perkinsus marinus (Perkins 1976) and P. olseni (= P. atlanticus) (Azevedo et al. 1990, Sagrista et al. 1996). Molecular studies have shown that $P$. atlanticus is conspecific with $P$. olseni (Robledo et al. 2000, Murrell et al. 2002). $P$. olseni was described first, and therefore takes precedence, and $P$. olseni will be used here to mean $P$. olseni and the species formerly called $P$. atlanticus. Under light microscopy, the prezoosporangia of Thai Perkinsus sp. varied in size from 25 to $75 \mu \mathrm{m}$, being smaller than size ranges reported for $P$. marinus (30 to $80 \mu \mathrm{m})$ (Perkins 1996), $P$. olseni $(=P$. atlanticus) (30 to $40 \mu \mathrm{m})$ (Azevedo 1989), and $P$. olseni (56 to $94 \mu \mathrm{m}$ ) (Lester \& Davis 1981) during sporulation. Several studies have reported that temperature and salinity are also the 2 major factors that regulate the zoosporulation process. Ahn \& Kim (2001) reported that development of free zoospores of Perkinsus sp. in Ruditapes philippinarum is temperature- and salinity-dependent; the process being favored by high temperature and high-salinity conditions. Similar results were also reported for the carpet shell clam $R$. decussatus in Galicia, NW Spain (Casas et al. 2002).

Histological examination of clam tissue from Perkinsus sp. in this study detected fewer infected clams than the FTM method. Our results support findings by Rodriguez \& Navas (1995), who concluded that positive results obtained by histological analysis may underestimate real infection levels in the field. Almeida et al. (1999) also reported that histological examination detected fewer infected clams than that revealed by whole-clam culture.

The microscopic appearance of the Perkinsus sp. infection in the clams include hemocyte infiltration, encapsulation and necrosis similar to those reported for $P$. olseni infecting the giant clam Tridacna maxima (Goggin \& Lester 1989), 
and P. olseni found in the carpet shell Ruditapes decussatus (Azevedo 1989) and the Manila clam R. philippinarum (Hamaguchi et al. 1998, Park \& Choi 2001, Choi et al. 2002). The size of trophozoites reported in this study is comparable to that for P. olseni (2 to $6 \mu \mathrm{m}$ ) (Goggin \& Lester 1989) and smaller than that for P. olseni found in $R$. philippinarun in Korea (5 to $14 \mu \mathrm{m}$ ) and Japan (5.3 to $32.5 \mu \mathrm{m}$ ) (Hamaguchi et al. 1998, Park \& Choi 2001).

In the present study, Paphia undulata infection by Perkinsus sp. was heaviest in the digestive gland. This finding is supported by the results of Park \& Choi (2001), who found that trophozoites were mostly concentrated in the gills and visceral mass, which includes the digestive gland. Several studies also reported that heavy infection of Perkinsus spp. in clams often results in milky-white pustule formation on clam mantle and gill tissues as a consequence of inflammation (Almeida et al. 1999, Park \& Choi 2001, Choi et al. 2002). However, no pustule or nodules were observed on the gill and mantle surfaces of clams in this study.

We found that some Thai Paphia undulata stocks appear to be heavily infected by Perkinsus sp. Heavy infections of this parasite have been reported to cause considerable damage to clam and oyster fisheries in many parts of the world (Goggin \& Lester 1987, Perkins 1988, Figueras et al. 1992, Choi \& Park 1997, Blackbourn et al. 1998, Bower et al. 1998, Casas et al. 2002, Hine \& Diggles 2002).

In conclusion, infection by the protozoan parasite Perkinsus sp. is highly prevalent in Thai populations of Paphia undulata, and there does not seem to be a clear seasonal (monsoonal) pattern of infection. The distribution of Perkinsus sp. infection in Thai clam harvesting grounds remains to be determined. Further investigation of these clams in natural harvesting grounds in conjunction with time and environmental factors will be necessary to determine patterns of infection and the potential effect of Perkinsus sp. on this clam. Microscopic features of different life stages indicate that Perkinsus sp. in Thailand closely resembles $P$. olseni (= P. atlanticus) reported from Australia, New Zealand, Korea, Japan, Spain and Portugal. This finding suggests that $P$. olseni (= P. atlanticus) is enzootic in the Southeast Asian/ Australasian or Indo-Pacific region.

Acknowledgements. We thank Dr. Pichai Sonchang, Director of the Institute of Marine Science, for use of laboratory facilities. Partial funding was provided by the Graduate School and Graduate Program in Biological Science, Faculty of Science, Burapha University, Thailand.

\section{LITERATURE CITED}

Ahn KJ, Kim KH (2001) Effect of temperature and salinity on in vitro zoosporulation of Perkinsus sp. in Manila clams Ruditapes philippinarum. Dis Aquat Org 48:43-46
Almeida MF, Berthe F, Thebault A, Dinis MT (1999) Whole clam culture as a quantitative diagnostic procedure of Perkinsus atlanticus (Apicomplexa, Perkinsea) in clams Ruditapes decussatus. Aquaculture 177:325-332

Andrews JD (1988) Epizootiology of the disease caused by the oyster pathogen Perkinsus marinus and its effect on the oyster industry. Am Fish Soc Spec Publ 18:47-63

Azevedo C (1989) Fine structure of Perkinsus atlanticus n. sp. (Apicomplexa, Perkinsea) parasites of the clam Ruditapes decussates from Portugal. J Parasitol 75:627-635

Azevedo C, Corral L, Cachola R (1990) Fine structure of zoosporulation in Perkinsus atlanticus (Apicomplexa: Perkinsea). Parasitology 100:351-358

BIMS (Bangsaen Institute of Marine Science) (2002) Marine environmental survey along the eastern coast of Thailand. Burapha University, Chonburi (in Thai with English abstract)

Blackbourn J, Bower SM, Meyer GR (1998) Perkinsus qugwadi sp. nov. (incertae sedis) a pathogenic protozoan parasite of Japanese scallops, Patinopecten yessoensis, cultured in British Columbia, Canada. Can J Zool 76:942-953

Bower SM, Blackbourne J, Meyer GR (1998) Distribution, prevalence and pathogenicity of the protozoa Perkinsus quagwadi in Japanese scallops, Patinopecten yessoensis cultured in British Columbia, Canada. Can J Zool 76: 954-959

Burreson EM, Ragone Calvo LM (1996) Epizootiology of Perkinsus marinus disease of oysters in Chesapeake Bay, with emphasis on data since 1985. J Shellfish Res 15:17-34

Bushek D, Ford SE, Allen SK Jr (1994) Evaluation of methods using Ray's fluid thioglycollate media for diagnosis of Perkinsus marinus infection in the eastern oyster, Crassostrea virginica. Annu Rev Fish Dis 4:201-217

Casas S, Villaba A, Reece KS (2002) Study of perkinsosis in the carpet shell clam Tapes decussatus in Galicia (NW Spain). I. Identification of the aetiological agent and in vitro modulation of zoosporulation by temperature. Dis Aquat Org 50:51-65

Choi KS, Park KI (1997) Report on occurrence of Perkinsus sp. in the Manila clam Ruditapes philippinarum in Korea. Korean J Aquacult 10:227-237

Choi KS, Wilson EA, Lewis DH, Powell EN, Ray SM (1989) The energetic cost of Perkinsus marinus parasitism in oysters: quantification of the thioglycollate method. J Shellfish Res 8:125-131

Choi KS, Park KI, Lee KW, Matsuoka K (2002) Infection intensity, prevalence and histopathology of Perkinsus sp. in the Manila clam, Ruditapes philippinarum, in Isahaya Bay, Japan. J Shellfish Res 21:119-125

Chu FLE, Greene KH (1989) Effect of temperature and salinity on in vitro culture of the oyster pathogen, Perkinsus marinus (Apicomplexa: Perkinsea). J Invertebr Pathol 53: 260-268

Chu FLE, La Peyre JF, Burreson CS (1993) Perkinsus marinus infection and potential defense-related activities in eastern oyters, Crassostrea virginica: salinity effects. J Invertebr Pathol 62:226-232

Crosby MP, Roberts CF (1990) Seasonal infection intensity cycle of the parasite Perkinsus marinus (and an absence of Haplosporidium spp.) in oysters from a South Carolina salt marsh. Dis Aquat Org 9:149-155

DOF (Department of Fisheries) (2002) Fisheries Statistics of Thailand for 1999. Fisheries Economics Division, DOF, Ministry of Agriculture and Cooperatives, Bangkok, Publ 10/2002

Figueras A, Jose A, Robledo F, Novoa B (1992) Occurrence of haplosporidian and Perkinsus-like infections in carpet- 
shell clams, Ruditapes decussatus (Linnaeus, 1758), of the Ria De Vigo (Galicia, NW Spain). J Shellfish Res 11: 377-382

Goggin CL, Lester RJG (1987) Occurrence of Perkinsus species (Protozoa, Apicomplexa) in bivalves from the Great Barrier Reef. Dis Aquat Org 3:113-117

Goggin GL, Lester RJG (1989) Parasites of the genus Perkinsus from reef bivalves. Proc 6th Int Coral Reef Symposium, Townsville, p 36 (Abstract)

Hamaguchi M, Suzuki N, Usuki H (1998) Perkinsus protozoan infection in short-necked clam Tapes (=Ruditapes) philippinarum in Japan. Fish Pathol 33:473-480

Hine PM, Diggles BC (2002) The distribution of Perkinsus olseni in New Zealand bivalve molluscs. Surveillance 29: 8-11

Howard DW, Smith CS (1983) Histological techniques for marine bivalve mollusks. NOAA Tech Memo NMFS F/NEC-25:

Lester RJG, Davis GHG (1981) A new Perkinsus species (Apicomplexa, Perkinsea) from the abalone Haliotis ruber. J Invertebr Pathol 37:181-187

Liang YB, Zhang XC, Wang LJ, Yang B, Zhang Y, Cai CL (2001) Prevalence of Perkinsus sp. in the Manila clam, Ruditapes philippinarum, along the northern coast of the Yellow Sea in China. Oceanol Limnol Sin 32:502-511 (in Chinese with English Abstract)

Mackin JG (1953) Incidence of infection of oysters by Dermocystidium in the Barataria Bay area of Louisiana. Proc Natl Shellfish Assoc 42:22-35

Montes JF, Durfort M, Garcia-Valero J (2001) Parasitism by the protozoan Perkinsus atlanticus favours the development of opportunistic infection. Dis Aquat Org 46:57-66

Murrell A, Kleeman SN, Barker SC, Lester RJG (2002) Synonymy of Perkinsus olseni Lester \& Davis, 1981 and $P$. atlanticusi Azevedo, 1989 and update on the phylogenetic position of the genus Perkinsus. Bull Eur Assoc Fish Pathol 22:258-265

Park KI, Choi KS (2001) Spatial distribution of the protozoan parasite Perkinsus sp. found in the Manila clams Ruditapes philippinarum, in Korea. Aquaculture 203:9-22

Editorial responsibility: Albert Sparks,

Seattle, Washington, USA
Perkins FO (1976) Zoospores of the oyster pathogen, Dermocystidium marinum. I. Fine structure of the conoid and other sporozoan-like organells. J Parasitol 62:959-974

Perkins FO (1988) Structure of protistan parasites found in bivalve molluscs. Am Fish Soc Spec Publ 18:93-111

Perkins FO (1996) The structure of Perkinsus marinus (Mackin, Owen and Collier, 1950) Levine, 1978 with comments on taxonomy and phylogeny of Perkinsus spp. J Shellfish Res 15:67-87

Ragone LM, Burreson EM (1993) Effect of salinity on infection progression and pathogenicity of Perkinsus marinus in the eastern oyster, Crassostrea virginica (Gmelin). J Shellfish Res 12:1-7

Ray SM (1966) A review of the culture method for detecting Dermocystidium marinum, with suggested modifications and precautions. Proc Natl Shellfish Assoc 54:55-69

Robledo JAF, Coss CA, Vasta GR (2000) Characterization of the ribosomal RNA locus of Perkinsus atlanticus and development of a polymerase chain reaction-based diagnostic assay. J Parasitol 86:972-978

Rodriguez F, Navas JL (1995) A comparison of gill and haemolymph assays for the thioglycollate diagnosis of Perkinsus atlanticus (Apicomplexa, Perkinsea) in clams, Ruditapes decussatus (L) and Ruditapes philippinarum (Adams and Reeve). Aquaculture 132:145-152

Sagrista E, Durfort M, Azevedo C (1996) Ultrastructural study of the parasite, Perkinsus atlanticus (Apicomplexa), on the clam Ruditapes philippinarum, in the Mediterranean. Sci Mar 60:283-288

Soniat TM (1996) Epizootiology of Perkinsus marinus disease of eastern oysters in the Gulf of Mexico. J Shellfish Res 15:35-43

Taveekijakarn P, Nash G, Somsiri T, Putinaowarat S (2002) Martelia-like species: first report in Thailand. Newsl Aquat Anim Health Res Inst 11(2):1-2

Tharnbuppha C (1996) Effect of floods on short-necked clam in the Upper Gulf of Thailand in 1995. Tech Pap 1/1996. Marine Fisheries Development Center, Bangkok (in Thai with English abstract)

Submitted: January 26, 2003; Accepted: December 26, 2003 Proofs received from author(s): July 30, 2004 